\title{
Effect of Rhizobacteria and Water Quality on Some Soil Properties and Nutrient Uptake of Barley under Water Stress
}

\author{
S.A.M. Abd El-Azeem and E.M. Hokam \\ Department of Soil and Water, Faculty of Agriculture, Suez \\ Canal University, Ismailia, Egypt.
}

\begin{abstract}
AREENHOUSE pot experiment was conducted to study the A effect of phosphate solubilizing bacteria (Azospirillum brasilense $\mathrm{AC} 1$ and Bacillus subtilis $\mathrm{AC} 2$ ) in combination with different water resources (River Nile, El-Salam Canal and diluted sea waters, 1:10) and soil moisture depletion, SMD, levels $(25,50$ and $75 \%$ of the soil field capacity, FC) on some soil properties (Soil pH, EC, available P and total bacterial counts) and barley (Hordeum vulgare var. Giza 28) grain yield and NPK uptake. The results indicated that use of diluted sea water for irrigation significantly reduced soil available $\mathrm{P}$ as compared to El-Salam canal and Nile waters. It also significantly increased soil $\mathrm{pH}$ values compared to Nile water. The results showed also that utilization of $A$. brasilense strain as inoculant for barley seeds significantly increased soil available $\mathrm{P}$ and decreased soil $\mathrm{pH}$ values compared to $B$. subtilis strain. Irrigating barley plants with the different water resources after depletion of $50 \%$ from soil FC significantly increased available $\mathrm{P}$ and decreased $\mathrm{pH}$ value as compared to 25 and $75 \%$ SMD levels. Soil salinity was found to be significantly decreased by irrigating the plants after SMD of 50 and $75 \%$ compared to $25 \%$. The highest soil available $\mathrm{P}$ and EC were obtained with the treatments Nile water $+A$. brasilense $+50 \%$ SMD and diluted sea water $+B$. subtilis $+25 \%$ SMD level, respectively. On the other hand, the maximum $\mathrm{pH}$ value was recorded in the treatment El-Salam canal water $+B$. subtilis $+25 \%$ SMD level. Counts of total bacteria in the rhizospheric soil of barley increased with increasing growth period reaching their highest after 90 days from sowing date. After that, the counts markedly decreased reaching their lowest figures after 120 days. However, total rhizospheric bacterial counts decreased with increasing SMD level from 25 to $75 \%$.
\end{abstract}

Utilization of diluted sea water for irrigating barley plants significantly decreased grain yield and NPK uptake as compared to the Nile water. The higher the salinity of irrigation water, the lower were the values of grain yield and $\mathrm{K}$ uptake. Inoculating barley seeds with $A$. brasilense AC1 significantly increased barley grain $\mathrm{N}$ uptake compared to B. subtilis AC2. Grain yield and NPK uptake were found to be significantly reduced with increasing level of SMD from $25 \%$ to $75 \%$ FC. The highest grain yield and $\mathrm{N}$ uptake values were obtained with the treatment El-Salam canal water + A. brasilense $\mathrm{AC} 1+25 \%$ SMD level. On the other hand, the highest grain $\mathrm{P}$ and $\mathrm{K}$ uptake were recorded under the treatments Nile water $+A$. brasilense $\mathrm{AC} 1+25 \%$ 
SMD level and Nile water $+B$. subtilis $\mathrm{AC} 2+25 \%$ SMD level, respectively.

Keywords: Barley yield, Nutrient uptake, Phosphate solubilization, Bacterial counts, Soil water depletion.

Water is a limiting factor for any agriculture development. Low-quality water for irrigation is one of the main targets of agricultural policy to face the urgent needs for increasing food production. Additionally, soil water not only could govern the soil physical condition, but also might affect the soil chemical and biological situations such as plant uptake of nutrients and activity of soil microorganisms. Therefore, management of soil water status is crucial in agricultural systems (Asgarzadeh et al., 2010). Under increasing impacts of global warming, effective water use and using minimum amounts of water for irrigation have become the most critical issues to be considered in irrigated agriculture. Water stress is the most common environmental stress that directly affect soil microbial population and activity (Sinegani and Maghsoudi, 2011). However, only few studies have tried to assess the effects of water stress on soil microbial activity.

Increasing soil water-holding capacity can be improving water availability to plants. This improvement leads to sustainable productivity because it encourages phosphorus utilization and arrests yield declines (Fan et al., 2005). On the other side, excesses irrigation water may result in loss of soluble phosphorus $(\mathrm{P})$ from soil to aquatic systems, (Shan et al., 2005, Styles et al., 2006 and Cournane et al., 2011). Gahoonia et al. (1994) and Gutierrez-boem \& Thomas (1999) reported that the increase in $\mathrm{P}$ diffusion with increasing soil water content has been suggested as a possible cause of larger barley relative response to $\mathrm{P}$ fertilizer under dry condition. However, it will take into account in the current investigation that irrigation water amounts applied for each treatment do not exceed the limit of soil field capacity.

Phosphorus is one of the essential macronutrients for plants and is applied to soil in the form of phosphatic fertilizers. Phosphorus and water deficits are important limiting factors in agricultural production. Several authors observed the interactions between phosphorus deficiency and water stress. For instance, Gutierrez-boem and Thomas (1999) reported that phosphorus deficiency and water stress decreased vegetative development, shoot growth, leaf area index, $\mathrm{P}$ absorption and concentration, and yield. Phosphorus deficiency and/or salinity significantly decreased whole barley growth, leaf water content (Zribi et al., 2011). The effect of both stresses was not additive since the response of plants to combined salinity and $\mathrm{P}$ deficiency was similar to that of plants grown under $\mathrm{P}$ deficiency alone. In addition, salt-treated plants exposed to P deficiency showed higher salt tolerance compared to plants grown with sufficient $\mathrm{P}$ supply. This was related to plant ability to significantly increase root: shoot dry weight ratio. 
Unfortunately, a large portion of soluble inorganic phosphate applied to the soil as chemical fertilizer is immobilized rapidly and becomes unavailable to plants particularly in alkaline soils (Sundara and Natarajan, 1997). The unmanaged use of phosphatic fertilizers has increased agricultural costs and instigated a variety of environmental problems (Del Campillo et al., 1999). Therefore, the concept of adding phosphate-solubilizing bacteria (PSB) to fertilizers as providers of soluble phosphorus presents an economically and environmentally promising strategy. The PSB play fundamental roles in biogeochemical phosphorus cycling in natural and agricultural ecosystems. These can transform the insoluble phosphorus to soluble forms $\left(\mathrm{HPO}_{4}{ }^{2-}\right.$ and $\mathrm{H}_{2} \mathrm{PO}_{4}{ }^{-}$) by acidification, chelation, exchange reactions, production of acid and alkaline phosphatases, $\mathrm{H}^{+}$protonation and polymeric substances formation (Delvasto et al., 2006). Therefore, the use of phosphate solubilizing rhizobacteria in agricultural practice would not only offset the high cost of manufacturing phosphatic fertilizers but would also mobilize insoluble phosphorus in the fertilizers and soils to which they are applied.

Barley (Hordeum vulgare L.) is an important food and fodder crop and is widely cultivated in saline areas as one of the salt tolerant crops. However, its growth and production is also greatly affected by salt stress. Improving the salinity tolerance of barley and increasing its productivity has been an important objective in many barley-breeding programs (Colmer et al., 2005). Therefore, the objective of this study was to examine the effect of phosphate solubilizing rhizobacterial strains (Azospirillum brasilense AC1 and Bacillus subtilis AC2) in combination with different irrigation water resources on nutrient uptake (NPK) as well as some soil chemical properties under water stress. The effect of treatments on rhizospheric soil bacterial populations was also investigated.

\section{Material and Methods}

\section{Rhizobacterial strains and seed inoculation}

Two strains of phosphate solubilizing rhizobacteria, Azospirillum brasilense $\mathrm{AC} 1$ and Bacillus subtilis AC2 were used in this experiment. The strains were isolated from the rhizospheric soil of clover, Ismailia, Egypt. The strains were selected based on a previous knowledge of their ability to solubilize inorganic phosphate and produce siderophores and indole acetic acid (IAA) (Abd ElAzeem et al., 2007a). Additionally, these strains have ability to promote wheat and faba bean growth and yield under greenhouse conditions (Abd El-Azeem et al., 2007b and 2008). In this experiment, the strains were grown in a $100 \mathrm{ml}$ conical flask containing $50 \mathrm{ml}$ of nutrient broth medium at $28^{\circ} \mathrm{C}$ for 4 days. The cultures were then diluted with sterilized distilled water to a final concentration of $10^{8}$ colony forming unit (CFU) $\mathrm{ml}^{-1}$. Barley seeds (Hordeum vulgare var Giza 28) were inoculated by soaking the seeds in nutrient broth medium for $1 \mathrm{hr}$ before cultivation. 10\% Arabic gum was used as an adhesive agent. 
Experimental layout and irrigation treatments

A greenhouse pot experiment was conducted in the farm of the Faculty of Agriculture, Suez Canal University, Ismailia, Egypt using a sandy soil sample (0-30 cm depth). The soil was air-dried, crushed and sieved through a $2 \mathrm{~mm}$ sieve. The selected properties of the soil were determined according to Gee and Bauder (1986) and Sparks et al. (1996) and presented in Table 1. Volumetric soil field capacity was determined in laboratory using tension table apparatus (Klute, 1986). The soil was uniformly packed in plastic pots of $17 \mathrm{~cm}$ height and 18.6 $\mathrm{cm}$ mean diameter at a rate of $5.0 \mathrm{~kg} \mathrm{pot}^{-1}$. A drainage hole of about $1 \mathrm{~cm}$ in diameter was made in the bottom of each pot. The experimental design was a randomized complete block (factorial) with three replications for each treatment. It included 18 treatments, which were the combinations of three irrigation water resources, three soil moisture depletion (SMD) levels $(25,50$ and $75 \%$ of the soil FC) and two rhizobacterial strains (Azospirillum brasilense AC1 and Bacillus subtilis AC2). The three irrigation waters used were El-Salam canal water (Nile water mixed with agricultural drainage water at a ratio of almost 1:1) sea water mixed with Nile water at a ratio of 1:10 and fresh Nile water as a control. Some chemical properties of the irrigation waters used are presented in Table 2.

TABLE 1. Physical and chemical properties of the soil used.

\begin{tabular}{|c|c|}
\hline Soil properties & Values \\
\hline \multicolumn{2}{|l|}{ Particle size distribution, $\%$} \\
\hline$\overline{\text { Sand }}$ & 93.4 \\
\hline Silt & 4.2 \\
\hline Clay & 2.4 \\
\hline Textural class & Sand \\
\hline Bulk density $\left(\rho_{\mathrm{b}}\right), \mathrm{kg} \mathrm{m}^{-3}$ & 1630 \\
\hline Field capacity $\left(\theta_{\text {f.c }}\right), \%$ & 11.2 \\
\hline $\mathrm{pH}^{*}$ & 7.13 \\
\hline $\mathrm{EC}_{\mathrm{e}}, \mathrm{dS} \mathrm{m}^{-1^{* *}}$ & 0.95 \\
\hline \multicolumn{2}{|l|}{ Soluble cations, meq $1^{-11^{* *}}$} \\
\hline $\mathrm{Ca}^{2+}$ & 3.49 \\
\hline $\mathrm{Mg}^{2+}$ & 1.05 \\
\hline $\mathrm{Na}^{+}$ & 4.18 \\
\hline $\mathrm{K}^{+}$ & 0.78 \\
\hline \multicolumn{2}{|l|}{ Soluble anions, meq $1^{-1^{* *}}$} \\
\hline $\mathrm{HCO}_{3}^{-}$ & 0.17 \\
\hline $\mathrm{Cl}^{-}$ & 7.84 \\
\hline $\mathrm{SO}_{4}^{-2}$ & 1.48 \\
\hline Available $\mathrm{P}, \mathrm{mg} \mathrm{kg}^{-1}$ & 10.82 \\
\hline Total $\mathrm{N}, \mathrm{g} \mathrm{kg}^{-1}$ & 0.11 \\
\hline Organic carbon, $\mathrm{g} \mathrm{kg}^{-1}$ & 0.98 \\
\hline
\end{tabular}

*In soil-water suspension $(1: 2.5)$.

${ }^{* *}$ In soil saturation extract. 
EFFECT OF RHIZOBACTERIA AND WATER QUALITY ON SOME SOIL ... 135

TABLE 2. Some chemical properties of the irrigation waters used.

\begin{tabular}{|c|c|c|c|}
\hline Parameters & $\begin{array}{c}\text { Nile } \\
\text { water }\end{array}$ & $\begin{array}{c}\text { El-Salam canal } \\
\text { water }\end{array}$ & $\begin{array}{l}\text { Diluted sea } \\
\text { water }\end{array}$ \\
\hline $\mathrm{EC}, \mathrm{dS} \mathrm{m} \mathrm{m}^{-1}$ & 0.36 & 0.80 & 7.40 \\
\hline $\mathrm{pH}$ & 7.95 & 7.27 & 7.67 \\
\hline \multicolumn{4}{|l|}{ Soluble cations, meq $1^{-1}$} \\
\hline $\mathrm{Ca}^{2+}$ & 0.97 & 1.65 & 6.0 \\
\hline $\mathrm{Mg}^{2+}$ & 0.60 & 2.41 & 9.0 \\
\hline $\mathrm{Na}^{+}$ & 1.64 & 3.56 & 57.5 \\
\hline $\mathrm{K}^{+}$ & 0.39 & 0.38 & 1.5 \\
\hline \multicolumn{4}{|l|}{ Soluble anions, meq $1^{-1}$} \\
\hline $\mathrm{Cl}^{-}$ & 1.50 & 4.19 & 49.0 \\
\hline $\mathrm{HCO}_{3}^{-}$ & 1.30 & 0.25 & 3.4 \\
\hline $\mathrm{SO}_{4}^{2-}$ & 0.80 & 3.56 & 21.6 \\
\hline SAR* & 1.85 & 2.50 & 21.0 \\
\hline
\end{tabular}

"SAR: Sodium adsorption ratio.

${ }^{* *}$ Sea water: Nile water $(1: 10)$.

After barley seed (Hordeum vulgare var. Giza 28) inoculation with the bacterial strains, eight seeds were immediately sown in each pot and irrigated with the fresh Nile water at FC for 15 days to insure full seed germination. After this period, the plants were thinned to four plants per pot. After that, the plants were periodically irrigated with the different tested waters after SMD of 25, 50 and $75 \%$ of the soil FC based on weight loss to monitor the depletion level at which the pots should be irrigated to bring them back to FC. The N, P and $\mathrm{K}$ fertilizers were applied at levels of $65 \mathrm{~kg} \mathrm{~N}^{-1} \mathrm{fed}^{-1}, 31 \mathrm{~kg} \mathrm{P}_{2} \mathrm{O}_{5} \mathrm{fed}^{-1}$ and $25 \mathrm{~kg}$ $\mathrm{K}_{2} \mathrm{O}$ fed $^{-1}$, respectively. The $\mathrm{N}$ and $\mathrm{K}$ fertilizers were applied in the forms of ammonium sulfate and potassium sulfate, respectively. Because of we used two phosphate solubilizing rhizobacterial strains in this experiment, half of the $\mathrm{P}$ fertilizer was added through single superphosphate $\left(\mathrm{SSP} 15.5 \% \quad \mathrm{P}_{2} \mathrm{O}_{5}\right)$ and the other half through rock phosphate (RP 27.3\% $\mathrm{P}_{2} \mathrm{O}_{5}$ ). After 135 days from sowing, plants were harvested, dried at $70{ }^{\circ} \mathrm{C}$ and the dry weights of grains were recorded.

Soil and plant analyses

The Kjeldahl method (Bremner, 1996) was used to determine the total $\mathrm{N}$ in grains, whereas the $\mathrm{P}$ and $\mathrm{K}$ contents were determined after wet digestion using a nitric-perchloric acid mixture $(4: 1 \mathrm{v} / \mathrm{v})$. The $\mathrm{P}$ in the extraction solution was measured spectrophotometrically using the molybdenum-blue method (Jackson , 1973) and the K was measured using a flamephotometer. The rhizosphere soil samples were collected from all pots at 30, 60, 90 and 120 days after sowing and analyzed for $\mathrm{pH}$, soil electrical conductivity (EC) and available P. Soil EC and $\mathrm{pH}$ were measured electrometrically using calibrated glass electrode and available $\mathrm{P}$ was determined by the Olsen extraction method (Jackson, 1973). 


\section{Soil bacterial population}

To evaluate the effect of the experimental treatments on soil microbial population in the rhizosphere soil of barley, bacteria were enumerated by the dilution plate method using tryptic soy agar (TSA) medium in all soil samples. The inoculated bacterial plates were incubated at $30{ }^{\circ} \mathrm{C}$ for $3 \mathrm{~d}$. The bacterial population density was expressed as colony forming units $(\mathrm{CFU}) \times 10^{\mathrm{n}} \mathrm{g}^{-1}$ oven dried soil, where $10^{\mathrm{n}}$ was the dilution factor (Pepper and Gerba, 2009).

Statistical analysis

One-way analysis of variance (ANOVA) and least significant difference (LSD) test were done at a 0.05 significance level using the Costat software (version 6.311) (Steel and Torrie, 1980). Additionally, four-way analysis of variance was conducted at a 0.05 significant level for treatments with time.

\section{Results and Discussion}

\section{Soil chemical properties}

Table 3 shows the main effects of irrigation water resources (IWRes), phosphate solubilizing bacteria (PSB) and soil moisture deletion (SMD) levels on rhizospheric soil $\mathrm{pH}$, soil salinity $\left(\mathrm{EC}, \mathrm{dS} \mathrm{m} \mathrm{m}^{-1}\right.$ ) and available $\mathrm{P}$ along barley growth period of 135 days. The data indicate that the soil $\mathrm{pH}$ values were found to be significantly raised due to utilization of El-Salam canal and diluted sea waters as compared to control (Nile water). Data in Table 3 also show that irrigating barley plants with diluted sea water caused significant increases in EC and decreases in available P compared to El-Salam canal and Nile waters. This is due to the higher salinity content of the diluted sea water (4736 ppm) compared to El-Salam canal water $(512 \mathrm{ppm})$ and Nile water $(230 \mathrm{ppm})$. These results are in agreement with those of Hussein et al. (2008) who found that use the diluted sea waters $(2500,5000 \mathrm{ppm})$ for irrigating sorghum plants caused increases in soil salinity and $\mathrm{pH}$ values compared to tap water.

Regarding the main effect of PSB on soil chemical properties, Table 3 also indicates that utilization of $A$. brasilense $\mathrm{AC} 1$ as an inoculant for barley plants significantly reduced soil $\mathrm{pH}$ values and increased available $\mathrm{P}$ as compared to $B$. subtilis AC2. This result was expected whereas $A$. brasilense strain proved to be more efficient in solubilizing inorganic phosphate than $B$. subtilis strain (Abd ElAzeem et al., 2007a).

Respecting the main effect of SMD levels on soil chemical properties, data in Table 3 show that use of different water resources for irrigation at SMD level of $50 \%$ FC significantly increased soil available $\mathrm{P}$ and decreased $\mathrm{pH}$ values as compared to SMD levels of 25. Table 3 also indicates that use of all water resources for irrigation at SMD levels of 50 and $75 \%$ resulted in significant decreases in soil salinity compared to $25 \%$. Data in Table 3 also shows that the values of soil $\mathrm{pH}, \mathrm{EC}$ and available $\mathrm{P}$ were significantly changed over the growth period of barley.

Egypt. J. Soil Sci. 54, No. 2 (2014) 
EFFECT OF RHIZOBACTERIA AND WATER QUALITY ON SOME SOIL ... 137

TABLE 3. The main effect of different irrigation water resources (IWRes), phosphate solubilizing bacteria (PSB) and soil moisture depletion

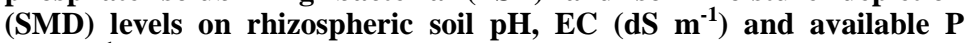
$\left(\mathrm{mg} \mathrm{kg}^{-1}\right)$ along barley growth period.

\begin{tabular}{lccc}
\hline & pH $^{\mathrm{a}}$ & EC $^{\mathrm{a}}$ & Available $^{\mathbf{b}}$ \\
\hline IWRes & $7.59^{\mathrm{c}}$ & $0.31^{\mathrm{b}}$ & $19.27^{\mathrm{b}}$ \\
River Nile & $7.72^{\mathrm{a}}$ & $0.34^{\mathrm{b}}$ & $20.33^{\mathrm{a}}$ \\
El-Salam Canal & $7.64^{\mathrm{b}}$ & $2.14^{\mathrm{a}}$ & $17.92^{\mathrm{c}}$ \\
Diluted sea water & 0.02 & 0.05 & 0.50 \\
L.S.D $_{0.05}$ & & & \\
\hline PSB & $7.60^{\mathrm{b}}$ & $0.94^{\mathrm{a}}$ & $19.59^{\mathrm{a}}$ \\
Azospirillum brasilense & $7.70^{\mathrm{a}}$ & $0.93^{\mathrm{a}}$ & $18.76^{\mathrm{b}}$ \\
Bacillus subtilis & 0.02 & 0.04 & 0.41 \\
L.S.D $_{0.05}$ & & & \\
\hline SMD & & $0.99^{\mathrm{a}}$ & $18.67^{\mathrm{b}}$ \\
25 & $7.67^{\mathrm{a}}$ & $0.89^{\mathrm{b}}$ & $20.17^{\mathrm{a}}$ \\
50 & $7.62^{\mathrm{b}}$ & $0.92^{\mathrm{b}}$ & $18.68^{\mathrm{b}}$ \\
75 & $7.65^{\mathrm{a}}$ & 0.05 & 0.50 \\
L.S.D $_{0.05}$ & 0.02 & & \\
Sampling time $_{3}$ days $^{\mathrm{e}}$ & & $0.69^{\mathrm{c}}$ & $19.44^{\mathrm{b}}$ \\
30 & $7.52^{\mathrm{c}}$ & $1.05^{\mathrm{a}}$ & $17.62^{\mathrm{c}}$ \\
60 & $7.45^{\mathrm{d}}$ & $1.03^{\mathrm{a}}$ & $21.80^{\mathrm{a}}$ \\
90 & $7.79^{\mathrm{b}}$ & $0.95^{\mathrm{b}}$ & $17.84^{\mathrm{c}}$ \\
120 & $7.82^{\mathrm{a}}$ & 0.05 & 0.58 \\
\hline L.S.D & 0.02 & & \\
\hline
\end{tabular}

in soil-water suspension $(1: 2.5),{ }^{\mathrm{b}} \mathrm{NaHCO}_{3}$-soluble $\mathrm{P},{ }^{\mathrm{c}}$ sea water : Nile water $(1: 10),{ }^{\mathrm{d}} \%$ of soil field capacity, ${ }^{\mathrm{e}}$ after sowing.

Concerning the effect of the interaction between IWRes, PSB and SMD levels on soil chemical properties, Table 4 indicates that the maximum $\mathrm{pH}$ value (8.21) was recorded with the treatment El-Salam canal water + B. subtilis $\mathrm{AC} 2+25 \%$ SMD level. On the other hand, the highest soil salinity $\left(2.80 \mathrm{dS} \mathrm{m}^{-1}\right)$ was obtained with the treatment diluted sea water $+B$. subtilis AC2 + 25\% SMD level (Table 5). The highest soil available $\mathrm{P}\left(35.93 \mathrm{mg} \mathrm{kg}^{-1}\right)$ was obtained under the treatment Nile water $+A$. brasilense AC1 $+50 \%$ SMD level (Table 6). These results indicate that utilization of diluted sea water caused significant increases in soil salinity. In this regard, Hokam (2013) reported that the salts were accumulated in all soils that treated with IWRes and SMD levels, because of rationally applied of irrigation waters (Limited amount of water that brings each treatment back to soil FC). Specifically, the use of different irrigation water resources at SMD level of $25 \%$ from soil FC caused salt accumulation in the soil when compared to 50 and $75 \%$ levels. This finding may be resulted because the $25 \%$ depletion-treatment was consumed water more than 50 and $75 \%$ levels. He also studied the leaching requirements (LR) of the soil and investigated the validation of common used Hoffman's equation for LR in comparison to Oster's equation, the comparison based on an experimental leaching curve. The results showed that there was an over estimation of LR obtained from Hoffman's equation compared to obtained from Oster's equation. At the same time, the amounts of water required for LR 
obtained based on Oster's equation could be reduced to about one-third of that calculated according Hoffman's equation, subsequently provision of large water amounts. Additionally, this study showed a great difference among LR values required according to the various salinity in waters used.

TABLE 4. Effect of the interaction between different irrigation water resources (IWRes), phosphate solubilizing bacteria (PSB) and soil moisture depletion (SMD) levels on rhizospheric soil $\mathrm{pH}$ along barley growth period.

\begin{tabular}{|c|c|c|c|c|c|c|c|}
\hline \multirow{2}{*}{ IWRes } & \multirow{2}{*}{$\begin{array}{c}\text { Time } \\
{\text { (days) })^{\mathrm{a}}}^{\text {a }}\end{array}$} & \multicolumn{3}{|c|}{ Azospirillum brasilense } & \multicolumn{3}{|c|}{ Bacillus subtilis } \\
\hline & & $25 \% \%^{b}$ & $50 \%{ }^{b}$ & $75 \% \%^{b}$ & $25 \%{ }^{b}$ & $50 \%{ }^{b}$ & $75 \% b$ \\
\hline \multirow{4}{*}{ River Nile } & 30 & 7.60 & 7.48 & 7.54 & 7.58 & 7.51 & 7.57 \\
\hline & 60 & 7.46 & 7.42 & 7.45 & 7.40 & 7.33 & 7.42 \\
\hline & 90 & 7.46 & 7.65 & 7.63 & 7.78 & 7.92 & 7.57 \\
\hline & 120 & 7.45 & 7.47 & 7.62 & 7.94 & 7.94 & 7.90 \\
\hline \multirow{4}{*}{$\begin{array}{l}\text { El-Salam } \\
\text { Canal }\end{array}$} & 30 & 7.60 & 7.48 & 7.56 & 7.52 & 7.49 & 7.61 \\
\hline & 60 & 7.41 & 7.50 & 7.51 & 7.64 & 7.50 & 7.57 \\
\hline & 90 & 7.76 & 7.72 & 7.81 & 7.81 & 7.73 & 8.02 \\
\hline & 120 & 7.86 & 8.03 & 7.96 & 8.21 & 7.87 & 8.02 \\
\hline \multirow{4}{*}{$\begin{array}{l}\text { Diluted } \\
\text { sea water }^{c}\end{array}$} & 30 & 7.48 & 7.43 & 7.44 & 7.53 & 7.53 & 7.46 \\
\hline & 60 & 7.61 & 7.15 & 7.23 & 7.55 & 7.45 & 7.44 \\
\hline & 90 & 7.71 & 7.27 & 7.91 & 8.13 & 8.03 & 7.91 \\
\hline & 120 & 7.86 & 7.80 & 7.69 & 7.71 & 7.70 & 7.76 \\
\hline
\end{tabular}

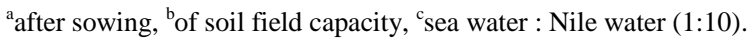

TABLE 5. Effect of the interaction between different irrigation water resources (IWRes), phosphate solubilizing bacteria (PSB) and soil moisture depletion (SMD) levels on rhizospheric soil electrical conductivity (EC,

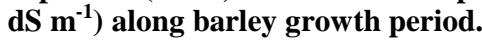

\begin{tabular}{|c|c|c|c|c|c|c|c|}
\hline \multirow{2}{*}{ IWRes } & \multirow{2}{*}{$\begin{array}{c}\text { Time } \\
\text { (days) }^{a}\end{array}$} & \multicolumn{3}{|c|}{ Azospirillum brasilense } & \multicolumn{3}{|c|}{ Bacillus subtilis } \\
\hline & & $25 \%^{b}$ & $50 \%^{b}$ & $75 \%^{b}$ & $25 \%^{b}$ & $50 \%{ }^{b}$ & $75 \% b$ \\
\hline \multirow{4}{*}{ River Nile } & 30 & 0.43 & 0.54 & 0.43 & 0.48 & 0.42 & 0.43 \\
\hline & 60 & 0.30 & 0.33 & 0.37 & 0.33 & 0.32 & 0.33 \\
\hline & 90 & 0.21 & 0.28 & 0.24 & 0.30 & 0.21 & 0.23 \\
\hline & 120 & 0.14 & 0.31 & 0.24 & 0.16 & 0.16 & 0.29 \\
\hline \multirow{4}{*}{$\begin{array}{l}\text { El-Salam } \\
\text { Canal }\end{array}$} & 30 & 0.41 & 0.47 & 0.38 & 0.48 & 0.40 & 0.45 \\
\hline & 60 & 0.36 & 0.32 & 0.37 & 0.21 & 0.29 & 0.39 \\
\hline & 90 & 0.37 & 0.28 & 0.30 & 0.29 & 0.43 & 0.41 \\
\hline & 120 & 0.24 & 0.29 & 0.20 & 0.24 & 0.36 & 0.30 \\
\hline \multirow{4}{*}{$\begin{array}{l}\text { Diluted } \\
\text { sea water }^{\mathrm{c}}\end{array}$} & 30 & 1.39 & 1.18 & 0.84 & 1.14 & 0.99 & 1.59 \\
\hline & 60 & 2.23 & 2.40 & 2.56 & 2.80 & 2.38 & 2.66 \\
\hline & 90 & 2.27 & 2.27 & 2.16 & 1.97 & 2.01 & 2.38 \\
\hline & 120 & 2.25 & 2.46 & 2.42 & 2.71 & 2.65 & 2.22 \\
\hline L.S.D ${ }_{0.05}$ & 0.22 & & & & & & \\
\hline
\end{tabular}

${ }^{a}$ after sowing, ${ }^{\text {b }}$ of soil field capacity, ${ }^{\text {c }}$ sea water : Nile water $(1: 10)$.

Egypt. J. Soil Sci. 54, No. 2 (2014) 
EFFECT OF RHIZOBACTERIA AND WATER QUALITY ON SOME SOIL ... 139

TABLE 6. Effect of the interaction between different irrigation water resources (IWRes), phosphate solubilizing bacteria (PSB) and soil moisture depletion (SMD) levels on rhizospheric soil available $\mathbf{P}\left(\mathrm{mg} \mathrm{kg}^{-1}\right)$ along barley growth period.

\begin{tabular}{|c|c|c|c|c|c|c|c|}
\hline \multirow{2}{*}{ IWRes } & \multirow{2}{*}{$\begin{array}{l}\text { Time } \\
\text { (days) }^{\mathrm{a}}\end{array}$} & \multicolumn{3}{|c|}{ Azospirillum brasilense } & \multicolumn{3}{|c|}{ Bacillus subtilis } \\
\hline & & $25 \%^{b}$ & $50 \%$ & $75 \% b$ & $25 \% b$ & $50 \% b$ & $75 \% b$ \\
\hline \multirow{4}{*}{ Nile River } & 30 & 14.37 & 35.93 & 19.16 & 20.42 & 19.42 & 20.76 \\
\hline & 60 & 17.06 & 12.61 & 18.57 & 18.91 & 14.25 & 14.62 \\
\hline & 90 & 20.93 & 17.57 & 16.39 & 16.81 & 18.41 & 35.55 \\
\hline & 120 & 24.46 & 22.06 & 15.89 & 15.04 & 13.95 & 19.42 \\
\hline \multirow{4}{*}{$\begin{array}{l}\text { El-Salam } \\
\text { Canal }\end{array}$} & 30 & 14.75 & 19.16 & 27.99 & 22.86 & 12.27 & 12.69 \\
\hline & 60 & 15.80 & 22.07 & 20.17 & 22.06 & 20.81 & 16.64 \\
\hline & 90 & 19.67 & 22.82 & 21.69 & 25.47 & 29.38 & 31.52 \\
\hline & 120 & 17.40 & 22.70 & 18.91 & 14.88 & 24.21 & 11.98 \\
\hline \multirow{4}{*}{$\begin{array}{l}\text { Diluted sea } \\
\text { water }^{\mathrm{c}}\end{array}$} & 30 & 26.48 & 29.00 & 12.36 & 13.61 & 17.02 & 11.60 \\
\hline & 60 & 15.38 & 15.64 & 18.91 & 15.63 & 15.38 & 22.57 \\
\hline & 90 & 17.65 & 22.27 & 15.63 & 23.07 & 19.42 & 18.16 \\
\hline & 120 & 17.06 & 22.70 & 14.12 & 18.28 & 15.13 & 12.99 \\
\hline
\end{tabular}

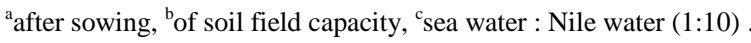

Rhizospheric soil bacterial populations

Table 7 shows that the bacterial counts increased as the plant growth period increased reaching their highest values after 90 days from sowing date in all experimental treatments. This could be explained by the presence of high amounts of easily decomposable organic materials and enrichment of rhizosphere zone with root exudates that encourage bacteria to proliferate. However, the bacterial counts sharply declined after 120 days from sowing in all tested treatments. This may be due to the stepwise exhaustion of available organic materials, which are necessary for growth of such heterotrophic bacteria. Table 7 also shows that the highest bacterial population $\left(39.52 \times 10^{6} \mathrm{CFU} \mathrm{g}^{-1}\right.$ dry soil) was found in soil irrigated with diluted sea water (1:10) under SMD level of $25 \%$ and inoculated with Bacillus subtilis strain. While, the lowest count $(1.17 \mathrm{x}$ $10^{6} \mathrm{CFU} \mathrm{g}{ }^{-1}$ dry soil) was recorded in soil irrigated with Nile water at $75 \%$ SMD level and inoculated with Azospirillum brasilense strain. Table 7 also indicates that the bacterial counts were found to be decreased with raising SMD level from $25 \%$ to $75 \%$. These findings may be attributed to the lowering intracellular water potential and thus reducing hydration and activity of enzymes. In addition, water availability affects the osmotic status of bacterial cells and can indirectly regulate substrate availability, diffusion of gases, soil $\mathrm{pH}$, and temperature. Furthermore, moisture deficit will stress plants and may affect bacterial communities through changes in rhizodeposition and nutrient allocation below ground. Ultimately, periods of moisture limitation may affect bacterial communities through starvation, induced osmotic stress, and resource competition, eliciting a strong selective pressure on the structure and functioning of soil bacterial communities (Arshad et al., 2006). In this respect, Chowdhury et al. (2011) found that, as 
saline soils dry, the salt in the remaining solution phase is concentrated and the microbes are subjected to both water and osmotic stress. They found that in both soils (sand and a sandy loam), microbial biomass decreased by $35-50 \%$ as water potential decreased to about $-2 \mathrm{MPa}$ but then remained stable with further decreases of water potential. Our results clearly indicated that the rhizosphere of barley irrigated with diluted sea water $(1: 10)$ had enriched bacterial populations compared to River Nile and El-Salam canal water.

TABLE 7. Effect of the interaction between different irrigation water resources (IWRes), phosphate solubilizing bacteria (PSB) and soil moisture depletion (SMD) levels on rhizospheric soil bacterial populations (CFU $\times 10^{6} \mathrm{~g}^{-1}$ dry soil) along barley growth period.

\begin{tabular}{|c|c|c|c|c|c|c|c|}
\hline \multirow{2}{*}{ IWRes } & \multirow{2}{*}{$\begin{array}{c}\text { Time } \\
{\text { (days) })^{a}}^{a}\end{array}$} & \multicolumn{3}{|c|}{ Azospirillum brasilense AC1 } & \multicolumn{3}{|c|}{ Bacillus subtilis AC2 } \\
\hline & & $25 \% \%^{b}$ & $50 \%$ & $75 \%^{b}$ & $25 \%$ & $50 \%{ }^{b}$ & $75 \%^{b}$ \\
\hline \multirow{4}{*}{ River Nile } & 30 & 13.64 & 11.65 & 10.29 & 24.02 & 18.71 & 16.80 \\
\hline & 60 & 14.41 & 12.24 & 11.87 & 28.82 & 22.48 & 16.74 \\
\hline & 90 & 16.81 & 13.11 & 12.18 & 31.22 & 24.35 & 18.05 \\
\hline & 120 & 4.19 & 3.92 & 1.17 & 2.51 & 1.80 & 1.44 \\
\hline Mean & & 12.26 & 10.23 & 8.88 & 21.64 & 16.84 & 13.26 \\
\hline \multirow{4}{*}{$\begin{array}{l}\text { El-Salam } \\
\text { Canal }\end{array}$} & 30 & 16.01 & 14.48 & 13.72 & 14.19 & 13.42 & 12.35 \\
\hline & 60 & 19.61 & 17.50 & 15.25 & 17.86 & 16.13 & 14.29 \\
\hline & 90 & 20.01 & 18.15 & 17.11 & 19.26 & 18.0 & 15.60 \\
\hline & 120 & 5.75 & 2.97 & 2.57 & 2.22 & 1.45 & 1.27 \\
\hline Mean & & 15.35 & 13.28 & 12.16 & 13.38 & 12.25 & 10.88 \\
\hline \multirow{4}{*}{$\begin{array}{l}\text { Diluted } \\
\text { sea water }\end{array}$} & 30 & 21.83 & 14.12 & 12.35 & 30.93 & 28.60 & 14.06 \\
\hline & 60 & 32.75 & 25.55 & 17.89 & 37.12 & 28.95 & 20.27 \\
\hline & 90 & 35.15 & 27.42 & 19.19 & 39.52 & 30.51 & 21.36 \\
\hline & 120 & 2.40 & 1.38 & 1.34 & 2.37 & 2.05 & 1.99 \\
\hline Mean & & 23.03 & 17.12 & 12.69 & 27.49 & 22.53 & 14.42 \\
\hline
\end{tabular}

${ }^{\mathrm{a}}$ after sowing, ${ }^{\mathrm{b}}$ of soil field capacity, ${ }^{\mathrm{c}}$ sea water : Nile water $(1: 10)$.

\section{Grain yield and NPK uptake}

Barley response to combination of different IWRes, PSB inoculants and SMD levels was evaluated by determining grain yield and NPK uptake of barley plants harvested after 135 days from sowing date. Concerning the main effect of IWRes on grain yield and NPK uptake, Table 8 shows that use of El-Salam canal and diluted sea waters for irrigation significantly decreased grain yield and $\mathrm{k}$ uptake as compared to the control (Nile water).

The higher the salinity of irrigation water, the lower were the values of grain yield and $\mathrm{K}$ uptake (Tables 2 and 8). Likewise, values of grain $\mathrm{N}$ and $\mathrm{P}$ uptake were significantly reduced due to irrigation with diluted sea water as compared to the Nile or El-Salam canal water. These results could be attributed to the harmful effects of salinity on the growth of barley plants. The harmful effects of salinity on plant growth include decreasing soil availability of nutrients (Table 3), reducing water absorption and metabolic activities (Mengel and Kirkby, 1982). The

Egypt. J. Soil Sci. 54, No. 2 (2014) 
adverse effect of irrigation water salinity on growth and nutrient uptake of plants was previously reported by many investigators. For instance, Hussein et al. (2008) found that irrigating sorghum with diluted sea water at salinity levels of 2500 and $5000 \mathrm{ppm}$ significantly decreased plant height, leaf area, number of leaves per plant and dry weight of plant as compared to tap water. Shaaban et al. (2008) found that the uptake of N, P and K by barley was significantly decreased as the salinity level of irrigation water increased from 0.40 to $9.0 \mathrm{dS} \mathrm{m}^{-1}$. Maksimovic and Lin (2012) reported that irrigation water salinity affects nutrient availability to plants in many ways. It modifies binding, retention and transformation of nutrients in soil and affects the uptake and/or absorption of nutrients by the root system.

TABLE 8. Effect of different irrigation water resources (IWRes) and phosphate solubilizing bacteria (PSB) on barley grain yield $\left(\mathrm{g} \mathrm{pot}^{-1}\right)$ and NPK uptake (mg plant $\left.{ }^{-1}\right)$ at different soil moisture depletion (SMD) levels.

\begin{tabular}{|c|c|c|c|c|c|c|}
\hline \multicolumn{3}{|c|}{ Treatments } & \multirow{2}{*}{$\begin{array}{l}\text { Grain } \\
\text { Yield }\end{array}$} & \multirow[b]{2}{*}{$\mathbf{N}$} & \multirow[b]{2}{*}{$\mathbf{P}$} & \multirow[b]{2}{*}{$\mathbf{K}$} \\
\hline IWRes & PSB & SMD, $\%^{*}$ & & & & \\
\hline \multirow{6}{*}{$\begin{array}{l}\text { River Nile } \\
\text { water } \\
\text { (Control) }\end{array}$} & \multirow{3}{*}{$\begin{array}{l}\text { Azospirillum } \\
\text { brasilense }\end{array}$} & 25 & $13.50^{\mathrm{b}}$ & $56.85^{\mathrm{a}}$ & $9.58^{\mathrm{a}}$ & $24.19^{\mathrm{ab}}$ \\
\hline & & 50 & $9.23^{\mathrm{e}}$ & $41.38^{\mathrm{b}}$ & $5.30^{\mathrm{def}}$ & $15.51^{\text {defg }}$ \\
\hline & & 75 & $5.60^{\text {gh }}$ & $21.59^{\mathrm{ef}}$ & $3.43^{\mathrm{fg}}$ & $10.18^{\mathrm{h}}$ \\
\hline & \multirow{3}{*}{ Bacillus subtilis } & 25 & $15.30^{\mathrm{a}}$ & $39.12^{\text {bcd }}$ & $9.32^{\mathrm{a}}$ & $28.55^{\mathrm{a}}$ \\
\hline & & 50 & $10.33^{\mathrm{de}}$ & $35.59^{\mathrm{bcd}}$ & $7.76^{\mathrm{abc}}$ & $16.03^{\mathrm{def}}$ \\
\hline & & 75 & $4.07^{\mathrm{i}}$ & $17.25^{\mathrm{f}}$ & $4.68^{\mathrm{efg}}$ & $7.88^{\mathrm{h}}$ \\
\hline \multirow{6}{*}{$\begin{array}{l}\text { El-Salam } \\
\text { canal water }\end{array}$} & \multirow{3}{*}{$\begin{array}{l}\text { Azospirillum } \\
\text { brasilense }\end{array}$} & 25 & $15.73^{\mathrm{a}}$ & $61.65^{\mathrm{a}}$ & $8.71^{\mathrm{ab}}$ & $26.09^{\mathrm{ab}}$ \\
\hline & & 50 & $12.13^{\mathrm{c}}$ & $56.49^{\mathrm{a}}$ & $7.11^{\mathrm{bcd}}$ & $22.83^{\mathrm{bc}}$ \\
\hline & & 75 & $6.70^{\mathrm{fg}}$ & $34.74^{\mathrm{bcd}}$ & $4.15^{\mathrm{def}}$ & $12.92^{\mathrm{de}}$ \\
\hline & \multirow{3}{*}{ Bacillus subtilis } & 25 & $14.43^{\mathrm{ab}}$ & $42.19^{\mathrm{b}}$ & $7.99^{\mathrm{abc}}$ & $25.19^{\mathrm{ab}}$ \\
\hline & & 50 & $11.20^{\mathrm{cd}}$ & $43.16^{\mathrm{b}}$ & $6.43^{\text {cde }}$ & $18.05^{\mathrm{cd}}$ \\
\hline & & 75 & $6.10^{\mathrm{fg}}$ & $29.32^{\mathrm{de}}$ & $4.50^{\mathrm{efg}}$ & $10.77^{\text {gh }}$ \\
\hline \multirow{6}{*}{$\begin{array}{l}\text { Diluted } \\
\text { water }^{* *}\end{array}$} & \multirow{3}{*}{$\begin{array}{l}\text { Azospirillum } \\
\text { brasilense }\end{array}$} & 25 & $7.43^{f}$ & $40.96^{\mathrm{bc}}$ & $5.07^{\mathrm{def}}$ & $12.14^{\text {efgh }}$ \\
\hline & & 50 & $5.37^{\text {ghi }}$ & $29.38^{\text {de }}$ & $3.47^{\mathrm{fg}}$ & $8.03^{\mathrm{h}}$ \\
\hline & & 75 & $4.10^{\mathrm{i}}$ & $22.22^{\mathrm{ef}}$ & $2.62^{\mathrm{gh}}$ & $7.89^{\mathrm{h}}$ \\
\hline & \multirow{3}{*}{ Bacillus subtilis } & 25 & $6.47^{\mathrm{fg}}$ & $30.73^{\text {cde }}$ & $5.21^{\mathrm{def}}$ & $11.28^{\text {fgh }}$ \\
\hline & & 50 & $4.73^{\mathrm{hi}}$ & $22.11^{\mathrm{ef}}$ & $3.31^{\mathrm{fg}}$ & $8.51^{\mathrm{h}}$ \\
\hline & & 75 & $2.13^{\mathrm{j}}$ & $5.35^{\mathrm{g}}$ & $0.68^{\mathrm{h}}$ & $2.05^{\mathrm{i}}$ \\
\hline \multirow{3}{*}{ IWR means } & River Nile & & $11.05^{\mathrm{a}}$ & $35.30^{\mathrm{b}}$ & $6.68^{\mathrm{a}}$ & $19.95^{\mathrm{a}}$ \\
\hline & El-Salam Canal & & $9.67^{\mathrm{b}}$ & $44.59^{\mathrm{a}}$ & $6.65^{\mathrm{a}}$ & $17.06^{\mathrm{b}}$ \\
\hline & Diluted sea water & & $5.04^{\mathrm{c}}$ & $25.12^{\mathrm{c}}$ & $3.40^{\mathrm{b}}$ & $8.32^{\mathrm{c}}$ \\
\hline \multirow[t]{2}{*}{ PSB means } & $\begin{array}{l}\text { Azospirillum } \\
\text { brasilense }\end{array}$ & & $8.87^{\mathrm{a}}$ & $40.58^{\mathrm{a}}$ & $5.61^{\mathrm{a}}$ & $15.96^{\mathrm{a}}$ \\
\hline & Bacillus subtilis & & $8.31^{\mathrm{b}}$ & $29.42^{\mathrm{b}}$ & $5.54^{\mathrm{a}}$ & $14.26^{\mathrm{a}}$ \\
\hline \multirow{3}{*}{ SMD means } & $25 \%$ & & $12.14^{\mathrm{a}}$ & $45.25^{\mathrm{a}}$ & $7.65^{\mathrm{a}}$ & $21.24^{\mathrm{a}}$ \\
\hline & $50 \%$ & & $8.83^{\mathrm{b}}$ & $38.02^{\mathrm{b}}$ & $5.57^{\mathrm{b}}$ & $14.83^{\mathrm{b}}$ \\
\hline & $75 \%$ & & $4.78^{\mathrm{c}}$ & $21.74^{\mathrm{c}}$ & $3.51^{\mathrm{c}}$ & $9.25^{\mathrm{c}}$ \\
\hline
\end{tabular}

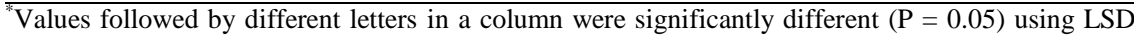
test of soil field capacity.

*** Sea water : Nile water $(1: 10)$. 
Regarding the main effect of PSB inoculants on grain yield and nutrient uptake, Table 8 indicates that the inoculation with $A$. brasilense AC1 caused significant increases in grain yield and $\mathrm{N}$ uptake as compared to B. subtilis AC2. However, no significant differences in grain $\mathrm{P}$ and $\mathrm{K}$ uptake were observed between the two bacterial strains. The superiority of A. brasilense $\mathrm{AC} 1$ on grain yield and $\mathrm{N}$ uptake over $B$. subtilis AC2 may be attributed to its higher ability to fix $\mathrm{N}_{2}$, solubilize inorganic phosphate and produce indole acetic acid (Abd ElAzeem et al., 2007a). In this regard, Hokam and Abd El-Azeem (2012) found that $A$. brasilense $\mathrm{AC} 1$ increased absorption of nitrogen by plant and subsequently increased the crop bear for salinity.

Respecting the main effect of SMD levels, data in Table 8 show that the grain yield and NPK uptake were found to be significantly decreased with increasing level of SMD from 25 to $75 \%$ of FC. This may be explained by limited total nutrient uptake and their diminished tissue concentrations in crop plants under water stress. In addition, water stress affects the acquisition of nutrients by the root and their transport to shoots. This lowered absorption of the inorganic nutrients can result from interference in nutrient uptake and the unloading mechanism, and reduced transpirational flow (Garg, 2003 and McWilliams, 2003). Moreover, the depletion of soil water from the root hair zone causes a gradient of soil water potentials between bulk and rhizospheric soil, which principally initiates a flow of soil solution from the bulk soil directed to the root surface or the root hair zone (mass flow).

Concerning the effect of the interaction between IWRes, PSB and SMD levels on grain yield and NPK uptake, Table 8 indicates that the highest barley grain yield and $\mathrm{N}$ uptake values were obtained when the plants were irrigated with El-Salam canal water at $25 \%$ SMD level, and inoculated with $A$. brasilense. On the other hand, the highest grain $\mathrm{P}$ and $\mathrm{K}$ uptake were recorded under the treatments Nile water plus A. brasilense plus 25 SMD level and Nile water plus B. subtilis plus $25 \%$ level, respectively. However, the lowest grain yield and NPK uptake were observed under the treatment diluted sea water $+B$. subtilis $+75 \%$ SMD level.

\section{Conclusions}

It could be concluded that from the obtained results that utilization of diluted sea water at salinity level of $4736 \mathrm{ppm}$ for irrigating barley plants at SMD levels of 25,50 and $75 \%$ significantly increased soil $\mathrm{pH}$ and soil salinity and decreased soil available P, grain yield and NPK uptake. Furthermore, use of diluted sea water $(1: 10)$ at the above SMD levels caused significantly reductions in barley grain yield and NPK uptake. Therefore, it is not recommended to use diluted sea water with the above salinity level or reach high SMD levels. In addition, our results indicated that water stress decreased the soil bacterial populations and these findings can be attributed by lowering intracellular water potential and thus reducing hydration and activity of enzymes. However, further research is needed to investigate the potential of continuous water stress in soil on soil microbial activity and soil enzymes in long term under field conditions.

Egypt. J. Soil Sci. 54, No. 2 (2014) 


\section{References}

Abd El-Azeem, S.A.M., Mehana, T.A. and Shabayek, A.A. (2007a) Some plant growth promoting traits of rhizobacteria isolated from Suez Canal region, Egypt. African Crop Science Conference Proceedings 8:1517-1525.

Abd El-Azeem, S.A.M., Mehana, T.A. and Shabayek, A.A. (2007b) Response of faba bean (Vicia faba L.) to inoculation with plant growth-promoting rhizobacteria. Catrina 2 (1):67-75.

Abd El-Azeem, S.A.M., Mehana, T.A. and Shabayek, A.A. (2008) Effect of seed inoculation with plant growth-promoting rhizobacteria on the growth and yield of wheat (Triticum aestivum L.) cultivated in a sandy soil. Catrina 3 (2):69-74.

Arshad, R., Farooq, S. and E-Azam, F. (2006) Rhizospheric bacterial diversity: is it partly responsible for water deficiency tolerance in wheat?. Pakistan Journal of Botany 38: 1751-1758.

Asgarzadeh, H., Mosaddeghi, M.R., Mahboubi, A.A., Nosrati, A. and Dexter, A.R. (2010) Soil water availability for plants as quantified by conventional available water, least limiting water range and integral water capacity. Plant and Soil 335: 229-244.

Bremner, J.M. (1996) Nitrogen-Total. In: "Methods of Soil Analysis", D.L. Sparks (Ed.), pp.1085-1122, Madison, Wisc.: ASA and SSSA.

Chowdhury, N., Marschner, P. and Burns, R.G. (2011) Soil microbial activity and community composition: Impact of changes in matric and osmotic potential. Soil Biology and Biochemistry 43: 1229-1236.

Colmer, T.D., Munns, R. and Flowers, T.J. (2005) Improving salt tolerance of wheat and barley: future prospects. Australian Journal of Experimental Agriculture 45:1425-1443.

Cournane, F.C., McDowell, R., Littlejohn, R. and Condron, L. (2011) Effects of cattle, sheep and deer grazing on soil physical quality and losses of phosphorus and suspended sediment losses in surface runoff. Agriculture, Ecosystems and Environment 140: 264-272.

Del Campillo, S.E., Van der Zee, S.E.A.T.M. and Torrent, J. (1999) Modelling longterm phosphorous leaching and changes in phosphorous fertility in selectively fertilized acid sandy soils. Eur. J. Soil Sci. 50: 391-399.

Delvasto, P., Valverde, A., Ballester, A., Igual, J.M., Munoz, J.A., Gonzalez, F., Blazquez, M.L. and Garcia, C. (2006) Characterization of brushite as a recrystallization product formed during bacterial solubilization of hydroxyapatite in batch cultures. Soil Biology and Biochemistry 38: 2645-2654.

Fan, T., Stewart, B.A., Yong W., Junjie, L. and Guangye, Z. (2005) Long-term fertilization effects on grain yield, water-use efficiency and soil fertility in the dryland of Loess Plateau in China. Agriculture, Ecosystems and Environment 106: 313-329.

Gahoonia, T.S., Raza, S. and Nielsen, N.E. (1994) Phosphorous depletion in the rhizosphere as influenced by soil moisture. Plant and Soil 159: 213-218. 
Garg, B.K. (2003) Nutrient uptake and management under drought: nutrient-moisture interaction. Current Agriculture 27: 1-8.

Gee, G.W. and Bauder, J.W. (1986) Particle-size analysis. In : "Methods of Soil Analysis" A. Klute (Ed.), pp. 383-409, Madison, Wisconsin: ASA and SSSA.

Gutierrez-boem, F.H. and Thomas, G.W. (1999) Phosphorus nutrition and water deficits in field-grown soybeans. Journal of Plant and Soil 207: 87-96.

Hokam, E.M. (2013) Simple approaches to quantify yield production and soil responsibility to different water qualities and moisture depletion. Journal of Soil and Water Sciences, Suez Canal University 1: 13-22.

Hokam, E.M. and Abd El-Azeem, S.A.M. (2012) Effects of water quality and moisture depletion on water consumption and barley yield inoculated with phosphate solubilizing bacteria. Egyptian Journal of Soil Science 52 (2).

Hussein, M.M., Abd El-Kadar, A.A., Kady, K.A. and Youssef, R.A. (2008) Effect of salinity and supplementary phosphorus and potassium on growth, yield, nutrition development and anatomical structure of sorghum plants. Egypt. J. Soil Sci. 48 (3): $399-414$

Jackson, M.L. (1973) "Soil Chemical Analysis", Prentice Hall of India Pvt. Ltd, New Delhi, India.

Klute, A. (1986) "Methods of Soil Analysis. Physical and Mineralogical Methods", $2^{\text {nd }}$ ed., number 9 , part 1 in the series of Agronomy. Madison, Wisconsin, USA.

Maksimovic, I. and Llin, Z. (2012) "Effects of Salinity on Vegetable Growth and Nutrients Uptake, Irrigation Systems and Practices in Challenging Environments", T.S. Lee (Ed.) .

McWilliams, D. (2003) Drought Strategies for Cotton, Cooperative Extension Service Circular 582, College of Agriculture and Home Economics, New Mexico State University, USA.

Mengel, K. and Kirkby, E.A. (1982) “Principles of Plant Nutrition", $3^{\text {rd }}$ ed. pp, 228-235, International Potash Institute, Worblanfen, Bern, Switzerland.

Pepper, I.L. and Gerba C.P. (2009) Cultural Methods. In: "Environmental Microbiology", R.M. Maier, I.L. Pepper and P.C., Gerba, $2^{\text {nd }}$ ed., pp. 173-183, Academic Press Elsevier Inc., UK.

Shaaban, M.M., Housein, M.M. and El-Saady, A.K.M. (2008) Nutrional status in shoots of barley genotypes as affected by salinity of irrigation water. American Journal of Plant Physiology 3 (2):89-95.

Shan, Y.H., Yang, L.Z., Yan, T.M. and Wang, J.G. (2005) Downward movement of phosphorus in paddy soil installed in large-scale monolith lysimeters. Agriculture, Ecosystems and Environment 111: 270-278. 
EFFECT OF RHIZOBACTERIA AND WATER QUALITY ON SOME SOIL ... 145

Sinegani, A.A.S. and Maghsoudi, J. (2011) The effects of water potential on some microbial populations and decrease kinetic of organic carbon in soil treated with cow manure under laboratory conditions. Journal of Applied Science and Environmental Management 15: 179-188.

Sparks, D.L., Page, A.L., Helmke, P.A., Loeppert, R., Soltanpour, P.N., Tabatabai, M.A., Johnston, C.T. and Sumner, M.E. (1996) "Methods of Soil Analysis", Madison, Wisconsin: ASA and SSSA.

Steel, R.G.D. and Torrie J.H. (1980) "Principles and Procedure of Statistics", McGrawHill Book Co., New York.

Styles, D., Donohue, I., Coxon, C. and Irvine, K. (2006) Linking soil phosphorus to water quality in the Mask catchment of western Ireland through the analysis of moist soil samples. Agriculture, Ecosystems and Environment 112: 300-312.

Sundara, B. and Natarajan, V. (1997) Effect of source and time of phosphorus application with and without phosphorus solubilizing bacteria on sugarcane. In: Proceedings of the Annual Convention of Sugar Technology Association of India, Goa, September 26-28, pp. 13-20.

Zribi, O.T., Abdelly, C. and Debez A. (2011) Interactive effects of salinity and phosphorus availability on growth, water relations, nutritional status and photosynthetic activity of barley (Hordeum vulgare L.). Journal of Plant Biology 13: 872-880. 


\title{
تأثير بكتيريا الجذور وجودة المياه علي بعض صفات التربة
} وامتصاص العناصر بواسطة الشعير تحت إجهاد مائى صلى

\author{
سامي عبد الملك محمد عبد العظيم و عصام محمد حكام

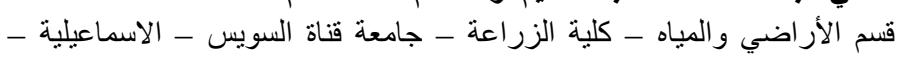

\begin{abstract}
تهذف هذه الدراسة إلى تقييم تأثيرات التلقيح ببكتيريا الجذور المذيبة للفوسفات وجودة مياة الرى على (Bacillus subtilis Azospirillum brasilense)

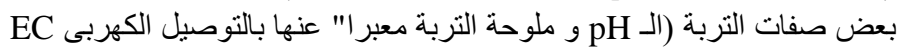

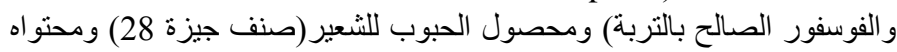

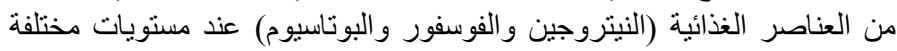

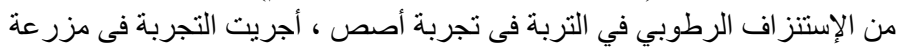

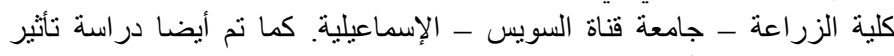

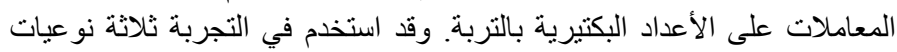

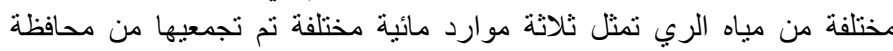

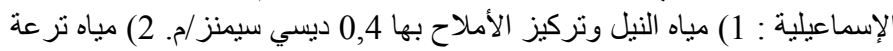

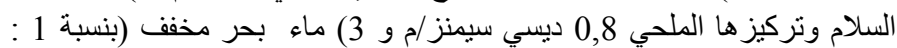

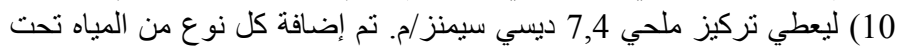

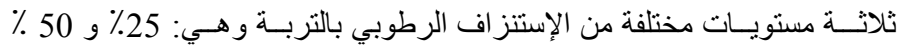
و 75\% من السعة الحقلية للتربة.
\end{abstract}

وقد أظهرت النتائج أن استخدام مياه البحر المخففة بنسبة 10:1 في الرى تقلئل

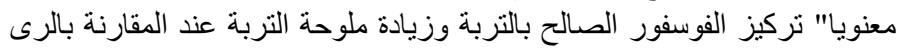

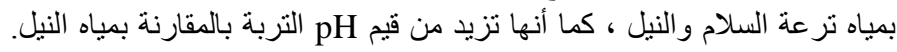

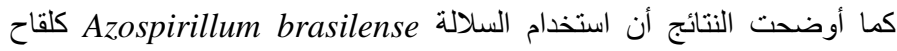

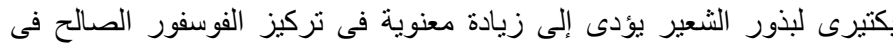

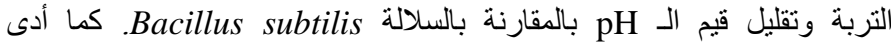

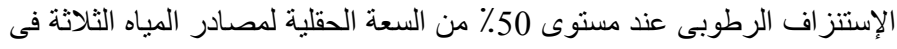

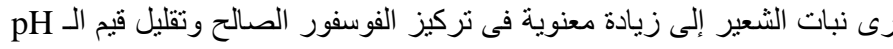

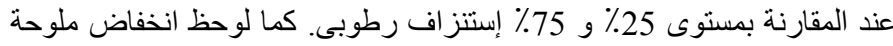

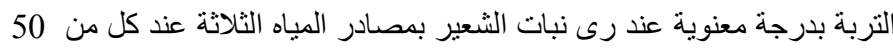

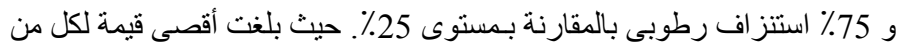
تركيز الفوسفور الصالح وملوحة التربة بمعاملتى الرى بلى بمياه النيل + التلقيح

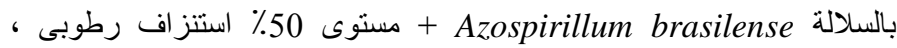

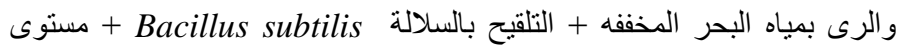

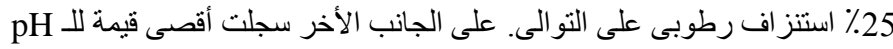

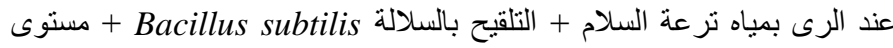

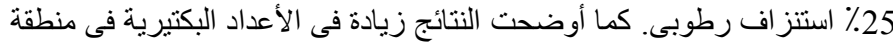

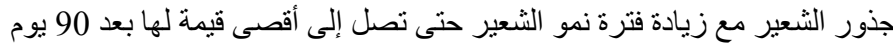

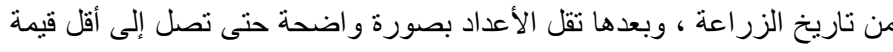

Egypt. J. Soil Sci. 54, No. 2 (2014) 
EFFECT OF RHIZOBACTERIA AND WATER QUALITY ON SOME SOIL ... 147

لها بعد 120 يوم من الزراعة. ومع ذلك وجد انخفاض هذه الأعداد مع زيادة

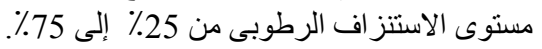

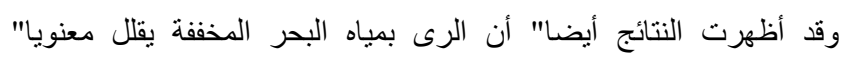

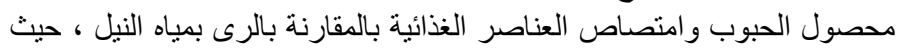

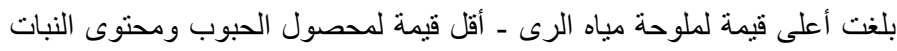

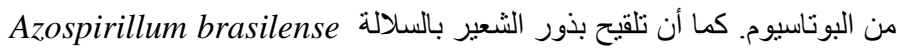

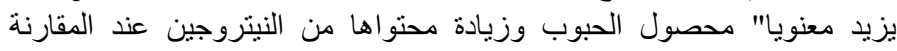

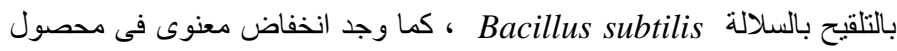

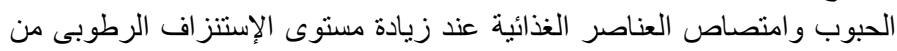

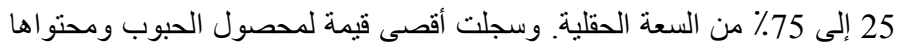

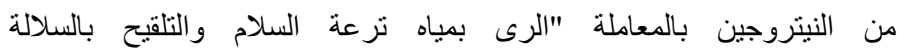
Azospirillum brasilense

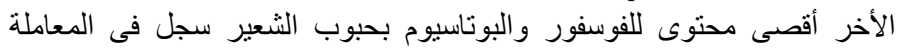

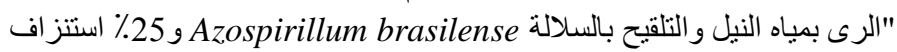
رطوبى" "والرى بمياه النيل و التلقيح بالسلالة Bacillus subtilis و 25٪

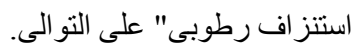

